\title{
THE PROBLEM OF ESTABLISHING WELFARE STATE MODELS, THEIR VALUES AND COHERENCE WITH THE PUBLIC ADMINISTRATION MODELS
}

\author{
Arvydas Guogis ${ }^{1}$, Adomas Vincas RaKŠnys² \\ Mykolas Romeris University (Lithuania), Kazimieras Simonavičius University (Lithuania)
}

\begin{abstract}
It is pointed in the article that a significant and relevant direction of new social sciences in the body of the problems of research into welfare states (in general) and in Central and Eastern European countries in particular, could be the investigation of the problem of compatibility and coherence between welfare state models and public administration models, to be more precise, examining if this relation is accidental or not. This problem of coherence between welfare state and public administration models has to be investigated empirically in subsequent research, as the author raises this problem firstly in this article theoretically.

KEYWORDS: welfare state models, public administration models, values, compatibility, coherence, New Public Governance.
\end{abstract}

\section{Introduction}

The economic approach in the modern world, including Central and Eastern Europe, has reached its apogee along with its economic indicators, such as promotion of competition or aiming at GDP growth, whereas individual success or failure is seen through the lens of the stories of micro-economic success or failure. P. Genschel, by referring to Garret's insights, properly notes (2004: 614) that "the globalization of markets seemed to leave governments with no choice but to pursue neo-liberal policies. "Good government" has become synonymous with "market-friendly government". Yet what actions encouraged this and what effect globalization and the economization of many areas has had on the values, political and administrative changes of a welfare state? Economic integration of states that was encouraged by the globalization since 1980 and economic crises that are becoming more intensive had influence on the changes of the welfare state. The influence of the political left and right on values and administrative systems conditioned various reform programmes, aiming at significantly reducing the role of the state and the administrative structures and functions by providing social services. The ongoing value changes encouraged the shift of priorities, by associating them with the programmes and projects ensuring the functions of a welfare state. In the countries of the post-Soviet bloc the critical assessment of a welfare state was influenced by the collapse of communism, when the ideas of communism were and still are associated with the ideas of "state socialism". In the context of globalization, in 2010s, one should not wonder at radical social system shifts in Poland, Hungary or, to a smaller extent, yet incremential shifts in Sweden, Germany, France, Italy (Kim, 2005: 377; Gizelis, 2005: 141; Stambolieva, 2015: 379).

\footnotetext{
Arvydas Guogis - professor at Institute of Public Administration, Faculty of Public Governance, Mykolas Romeris University, Vilnius, Lithuania

Scientific interests: social security, globalization and social policy, new public governance

E-mail: arvydasg@mruni.eu

2 Adomas Vincas Rakšnys - PhD student, Lecturer at Business School, Kazimieras Simonavičius University, Vilnius, Lithuania Scientific interests: public management, organizational culture

E-mail: e_cnv@yahoo.com
} 
On the other hand, these processes may be explained also by changing needs of the electorate of the political parties and their cycles. Green-Pedersen and Jensen note (2019: 803-805) that both the political right and the political left are constantly competing with each other for the attention of the voters. This attention is significantly associated with the actualization of the existing problems and election needs in the context of a welfare state. Yet the changing needs and values of voters condition also the shift of the priorities of the traditional political structures. In post-industrial economy the political left, which would traditionally represent the interests of the less educated working class, currently focus more on the educated middle-class due to more social-cultural rather than economic reasons related to redistribution and those related to a welfare state. For these processes, also transition from the more industrial to more service sector, individual experience with social programmes, the shift of the voters' personal values, demographic distribution are more common (Gingrich, Häusermann, 2015: 52-54; Lynch, Myrskylä, 2009: 1072; Green-Pedersen, Jensen, 2019: 804-805). It is noteworthy that "at the domestic level, a rapidly aging population and a shrinking labour force poses markedly higher future costs for maintaining welfare benefits at current levels for most European states" (Gizelis, 2005: 140). Hence the behaviour of the voters may be seen as a factor determining the shifts of the value priorities, political parties, welfare state and administrative systems.

Modern world raises especially difficult challenges and issues to mind and the development of activities. The theories and decisions of the 20th century often are not in line with the new, complicated conditions of the global 21st century, when former regularities are not valid anymore, the demographic and climate change is happening, there are huge emigrations waves, the development of international relations is contradictory (Keskinen, 2016: 353; Genschel, 2004; Gizelis, 2005), and the development of technologies is unimaginably rapid. We are on the verge of something very big and new, when the old things are not valid anymore, and the new has not been created yet; therefore, even timid novel attempts shoud be encouraged, approved more often than blocked, not debarred and delimited. Social problems, such as social guarantees for self-employed, reintegration of the persons in social exclusion, budget deficits of social protection and multiple other issues make us look for ways to achieve social stabilization in tense global and local situations. Yet globalization itself has not only positive but also negative effects, as glocalization is thriving along with it, which is restricting everything, and individual states start seeking 'closure' rather than 'openness' so that they are able to control the undesired phenomena. Likewise, for example, in Europe integration aims to create supranational political and economic institutions that seem to challenge the primacy of the nation state and its effectiveness to regulate the welfare of its citizens (Gizelis, 2005: 140).

In the article of the authors', the problem of coherence of welfare state and public administration models is raised and formulated on the basis of a descriptive and comparative method and critical analysis, which later on, upon verification of it in practice and upon completion of broader interdisciplinary research in social and humanitarian sciences, is likely to receive approving or, on the contrary, disproving assessments and feedback.

\section{On the issue of welfare state models and their values}

One of the concepts contradicting to the all-encompassing 'neoliberal economization' is the so-called theory and practice of Western 'welfare states', the value basis of which is made not only of economics but also other social and humanitarian sciences. They are concerned not only with what is egoistic but also with what is altruistic; not only with what is private, but also with what is and has to be public; not only with macro-economic but also with macro-social indicators; not only with the economic but also social value, which may not necessarily be possible to express in quantitative terms and calculate. But naturally question appears, where is the difference between the traditional state and welfare state concepts? According R. Harisalo and J. McInerney (2008), "the state has four major institutional tools available to promote its purposes. These are: services, regulation, financial transfers, and delegation to local government". A welfare state is not only an economically strong state but also a society that is built on the value-laden foundations of solidarity and relative equality under the conditions of capitalism. According S. Keskinen (2016: 354), the establishment of the welfare model not only was an economic and social process, but was also about cons- 
tructing national identities. This process historically was related to such specific cultural elements as values implementation in the political and administrative system. As T. Gizelis writes, "western welfare states have three primary goals: redistribution, efficiency, and social cohesion" (Gizelis, 2005: 142).

The measures and instruments of the state in such a welfare state are directed to the mitigation of sharp contradictions of capitalism, manifestation of relative equality, and first of all - manifestation of equal opportunities and humanity. In a welfare state, the national dimension and national values have not been denied. In the most general terms, the definition of a welfare state could be as follows. A welfare state is the body of the measures of the social policy and administration of the state, first of all - in the area of social protection, which is supplemented by the measures of non governmental organizations and private sector aiming at not only economic efficiency but also social justice in the direction towards a sustainable state and development of society. Should the definition of a welfare state single out 'a welfare society' rather than 'a welfare state', in the view of the author, such a definition would lose its right to be seen from the lens of social justice achievement in the entire problematics of a welfare state with all the consequential methodologies and ideological implications. It is exactly the emphasis of 'a welfare society' rather than 'a welfare state' that is more characteristic of the representatives of modern neoliberalism in the entire world both in the terms of values and practical welfare achievement, yet it has huge drawbacks as a result of widespread phenomena of social injustice, poverty and social exclusion. Nowadays are forming also other aspects of welfare state, which are expressed, for example, as outlined by S. Keskinen, "welfare nationalism" aspect: "In which welfare and national identity are intertwined and welfare provision is based on national membership. In such discourses, the welfare state and its future are presented as a national concern that should be the focus of politics and economy (...) Welfare chauvinism frames welfare provision as reserved only 'for our own' in the sense that belonging or non-belonging is based on (ethno) nationalist, othering and often racialising criteria. I use welfare exclusionism to refer to discourses and ideologies in which welfare provision is reserved only for a part of those who live and work in the country, not for all with a residence permit. This includes views and policies that deny or condition access to income benefits or social services for migrants and their descendants even after they have lived in the country for several years and gained a permanent residence permit" (Keskinen, 2016: 355).

During the last three decades welfare states in Western Europe have somewhat retreated, yet they did not collapse. Their 'golden age' was in 1950s to 1975, yet even today, under the conditions of globalization, they are still constructed on the basis of the same value-moral foundations. According P. Genschel (2004: 615), „the welfare state steps in where the market fails, but can do so only if it is not exposed to market forces itself. Globalization, however, subjects the welfare state to the market pressures of international competition and thus inevitably undermines its viability and effectiveness". And it is hardly possible that their current, even not 'silver' but 'bronze age' (Moreno, 2016) will turn into 'iron age'. One can see evident shifts of showing interest in the welfare state both worldwide especially now, when neoliberal development has exhausted its possibilities and does not look like the only progressive direction of the movement. Especially it was the last global economic crisis of 2008-2010 that 'helped' to understand this. It resulted in louder discussions on social injustice and exclusion both in the public space in the world and in Europe. This discussion was too late, yet the macrosocial indicators achieved do not allow to continue being silent and wait for these problems, with improving economic situation, to be solved automatically (Mykolaityte, 2019). To achieve a social balance it is necessary to ensure a strong welfare state. From the methodological point of view, today it is already possible, by making a scientific-ideological cross-section of the entire country (or countries), to group them according to the categories of decommodification, public/private ratio and other categories. Today, for example, Lithuania may be seen only as a minimum post-communist corporate-bismarckian-clientelistic type welfare state, slowly drifting to a liberal-marginal type. Why liberal as well as 'marginal'? Since this type generates marginal groups, social exclusion. This, according to the methodology of G. Esping-Andersen, may be proven not only in qualitative but also quantitative terms (Esping-Andersen, 1990). The significance of a welfare state has long been substantiated, there are many of Western authors published (Keskinen, 2016; Gizelis, 2005; Gingrich, Häusermann, 2015; Bannink, Hoogenboom, 2007; Ha- 
risalo, McInerney, 2008; Lynch, Myrskylä, 2009; Genschel, 2004; Green-Pedersen, Jensen, 2019) and tens of conferences held for this purpose, only in Eastern and Central Europe there are still countries that want to turn their still not developed welfare states into substitute 'welfare societies', which in fact ensure welfare only to a handful of the chosen ones and indeed do not want and attempt to develop a middle class, and make the marginals leave their social exclusion.

There are no ideal models of welfare states in practice. Yet individual countries, such as Sweden, Germany or the USA are closest to the typical models of welfare states, as they were taken in mind by R. Titmuss (Titmuss, 1958; 1974), and later depicted by G. Esping-Andersen (Esping-Andersen, 1990), as institutionaluniversal-redistributive-socialdemocratic (Beveridgean) in the Nordic countries, industrial achievementscorporative-conservative (Bismarckian) in the continental Western European states and liberal-marginal (residual) in the anglo-saxon countries. The institutional-socialdemocratic model methodologically is based on the social rights, corporative-conservative model is based on the labour market and family, and liberalmarginal model methodologically is based on the market values. One of the most important criterias for this division is qualitative and quantitative public/versus/private relation in each of the models and the calculation of decommodification indexes. The authors of the article clearly follow this division of welfare states theoretically as proven empirically, also adding the subsequently defined models to this typology as corporative-Bismarckian-conservative-clientelistic model in Southern European countries (Ferrera, 1996) and postcommunist corporative-Bismarckian-clientelistic model in Central and Eastern European countries (Fenger, 2007; Aidukaite, Bogdanova, Guogis, 2012). Overall, the concepts of the existing welfare state may be divided into several categories. First, a welfare state is a certain stage of social development. With social development, a certain type of the society is created, which due to the development of production is characterized as material abundance, freedom or tolerance, which is determined by political development. This special type of the society extends the opportunities of the state, especially in meeting material needs of the citizens. A welfare state is defined as an inevitable relation with material abundance and civic freedoms, hence it is only possible in a developed capitalist society, since, for example, in the countries of former (Soviet Union, Albania) or existing (Cuba, North Korea, Belarus) state socialism the civic rights were not and are not ensured. Other Central and Eastern European countries, for example, in former Yugoslavia have shown different welfare developments. So, Slovenia's welfare model became an example of mixed corporative conservative (Bismarckian) and social-democratic (Beveridgean) system. Minor reforms, such as the introduction of a supplementary pension scheme based on individualized savings, voluntary health insurance, active labor market measures, have been undertaken; however, the state retained its stronghold. Similarly, Croatia kept the mixed Bismarckian / Beveridgean model, while introducing some (neo)liberal elements promoted by the international financial institutions. Despite reforms, various exceptions made to dampen their adverse effects or to preserve privileges have diluted the new elements. Serbia's and Montenegro's welfare systems suffered tremendously during the 1990s when their functionality was brought under question. The overthrow of the previous political regime allowed the two countries to rebuild their systems (Stambolieva, 2015: 383).

In the past three decades, Western welfare states have been overrun by multifarious reforms. Social security benefits have been substantially reduced in many countries, eligibility rules have been significantly tightened and in many cases the administration of the arrangements has been drastically revised (Bannink, Hoogenboom, 2007: 19).

A welfare state may be defined as a lifestyle. According to this interpretation, the concept of a welfare state is explained as the person's behaviour in the society. The residents of such countries have an individual lifestyle, yet the fundamental life conditions are ensured to them by the society. A welfare state contains social measures organized and implemented firstly by state, only afterwards by non-governmental and private organizations. Nowadays it is attempted to rationally reduce huge influence of the state. The residents appreciate the values of freedom, equality and solidarity. Third, part of people single out the political essence of a welfare state (Cousins, 2005). They see it as 'a collection of social and economic policy', when the welfare of citizens consists of old-age and unemployment benefits and state healthcare. The relation of all the kinds of state policies makes people to include any government (state) policy into the concept of a welfare state. 
Upon inclusion of all the aspects of a state policy into such a concept, it becomes similar to a welfare state as a stage of development of the society. Fourth, part of people give most attention to the governance style of the state. They claim that during the second half of the 20th century the governments of almost all industrial countries significantly extended the bureaucratic apparatus. In their opinion, the bureaucratic system is the most important feature of a welfare state.

Welfare states may be divided based on a philosophical approach, since this division is characteristic of not only gnoseological (knowledge) approach, but also, due to its 'social sensitivity', on the ontological (being) and axiological (values) aspects. Welfare states are divided also on the socio-political approach that is on the aspects of economics, sociology and political science. This way the liberal marginal welfare state gives priority to the market. The most typical countries of this model are Anglo-Saxon countries. A conservative corporative (Bismarckian) welfare state gives priority to dependence on the labour market and family. The most typical countries of this model are continental Western European countries, which first of all may be divided into countries that are more to the North, South and East. Some authors, for instance, Ferrera, single out a separate type of this model of countries - the countries of Southern Europe that have more features of clientelism (Ferrera, 1996), for the definition of which names of the model of the Mediterranean and Roman model are used. European Union countries of Central and Eastern Europe also have a number of features of the latter model - hence, they could be singled out as a separate group of countries (Kaarlainen, Lehtonen, 2006; Aidukaite, Bogdanova, Guogis, 2012; Pop Radu, 2014), which is divided by some of the authors into several more groups of states (Skuodis, 2009; Tache, Neesham, 2011; Lauzadyte-Tutliene, Balezentis, Goculenko, 2018). A universal institutional social-democratic welfare state gives priority to the state and social citizenship, social equality and solidarity is important to it. The most typical country of this model is Sweden along with four other countries of Northern Europe.

\section{On the problem of compatibility and coherence of welfare states and public} administration models in CEECs

A significant and relevant direction of new social sciences in the body of the problems of research into welfare states (in general) and in Eastern European countries in particular, could be the investigation of the problem of coherence between welfare state models and public administration models, to be more precise, examining if this relation is accidental or not. The aim of this kind of research would be to establish the logical, rational, not contradicting to itself relation of the models, which would encourage so effective public administration that would allow reaching the social aims of creation of an efficient welfare state. But if the contradictions appear between the latter and the former, the researchers' aim is to reveal these contradictions, to show their theoretical and practical incompatibility, and to suggest a more rational and logical way to overcome these contradictions for sustainable grounding and implementation.

Theoretically, the liberal-marginal welfare state model, which is based on the market, generates New public management model and vice/versa (as private sector's principles and methods in Anglo-Saxon countries), the corporative - conservative welfare state model, which is based on 'Bismarckian' conservative principles and methods, coincides more with the Hierarchical model (as labour market principles and methods in continental Western European countries), and certain traits of New public governance model are found in the Nordic countries, corresponding more to universal - redistributive social-democratic welfare state model, which is based on social citizenship. The question actually arises to examine the interaction of these models in CEECs, in which the mixed features of certain minimal welfare states are prevailing with the more visible characteristics of a 'Bismarckian' - corporative conservative model along with clientelism, and the shift to marginal-liberal model is noticed as well. However, because of the features of clientelism of a welfare model - nepotism, corruption, protectionism, lack of social capital, insufficient activities of NGOs and political organizations, the necessity for better public administration in the form of New Public Governance in CEECs is on the agenda. In addition, it is necessary to take into account the importance of multilevel governance in the majority of CEECs as EU 
countries (Moreno, 2018). New Public Governance is of vital importance in CEECs for its values and methods enabling openness, transparency, participation, pluralism, democracy, social justice, social responsibility, social quality, interorganizational and intersectoral cooperation, non-corruption, an active role of non-governmental organizations. These values and methods appear to be decisive not only in the final stage of reaching results, but they also penetrate into the very lasting administrative process in order to reach these results. It is rather obvious that the model of New Public Governance is more socially orientated than the Hierarchical and, especially, New Public Management model. In this regard, the most generic definition of the models of public administration can be provided here both with regard to theoretical - normative, and practical - implementation approach, as a means to formulate and implement the practices of public administration.

The previous social research investigated the welfare states/societies and public administration models separately, without trying to combine them worldwide (Kim, 2005; Green-Pedersen, Jensen, 2019; Stambolieva, 2015; Harisalo, McInerney, 2008; Gingrich, Häusermann, 2015; Gizelis, 2005). As we have outlined above, the models of welfare states were defined and investigated by Titmuss, Esping-Andersen, Ferrera et al. Sociologist Titmuss distinguished the main three models: a marginal-residual, industrial achievements and universal-institutional-redistributive models. Esping-Andersen developed the welfare typology by introducing not only qualitative parameters (public versus private, etc.), but also quantitative indicators (decommodification and stratification) and adjusted this theory to political science, defining liberal, conservative and social-democratic models (Bannink, Hoogenboom, 2007). Italian researcher Ferrera added the fourth welfare state model of a Mediterranean - South European type, Kaarlainen, Lehtonen (Kaarlainen, Lehtonen, 2006), Fenger (Fenger, 2007) started talking about a separate post-communist Eastern European model (both latter models having features of clientelism, Aidukaite, Bogdanova, Guogis, 2012).

On the other hand, Weber developed a hierarchical public administration model by indicating its 'bureaucratic pyramid'. Hood (Hood, 1991), Osborne, Gaebler (Osborne, Gaebler, 1992) defined the New Public Management model which was already practically implemented in Anglo-Saxon countries after Thatcher-Reagan reforms. New Public Governance was a development of the public administration theory and practice in the Western world (Pollitt, Bouckaert, 2011) and more theoretically - in Central and Eastern Europe (Guogis, 2013; Rakšnys, Guogis, Minkevičius, 2015). The necessity for New Public Governance in CEECs is postulated as having more of social value, as it was pointed above, than New Public Management and Hierarchical models. In any case, this research question of finding the coherence between the models of welfare states and public administration models has the focus on the effective public administration and active social policy in CEECs in general, and the suitability / non-suitability of these models for the social aims in particular. From the authors' point of view, the proposition of the universal-institutional-redistributive model and New Public Governance (and established coherence between them) can contribute to the public discourse on the elimination of nepotism, corruption, protectionism, not sufficient activities of NGOs and political organizations and the encouragement of cooperation, social justice, social responsibility, social equality and social inclusion. It is important at this stage of development and problem solving and in this stage of research that it is easier to describe the necessity of New Public Governance by theoretical principles as a normative public administration model, but it is more difficult to describe it by practical implementation methods and practical tools. In terms of the perspectives in the related subject, with gaining more practical results and making more values evident in the development of welfare states, public administration and research of welfare states and New Public Governance, it can be argued that more empirically based projects and publications will appear in social and humanitarian sciences too.

\section{Conclusions}

1. A welfare state contains social measures organized and implemented firstly by state, only afterwards by non-governmental and private organizations.

2. The models of public administration theoretically and practically express the measures by creating the practices of public administration. 
3. The problem of coherence of welfare states and public administration models is relevant in attempting to avoid the contradictions in the creation of welfare states.

4. If consider the social aims, the most valuable coherence between the models of welfare states and public administration may be shown as achieving the compatibility of the universal institutional-redistributive welfare model and the New Public Governance model. This kind of conclusion, at least theoretically, may be seen not only considering the problems of Western countries, but also considering Central and Eastern European countries.

5. Having founded the problem of coherence between welfare states and public administration models, later on, in the longer term perspective, it is useful to implement the respective practices and scientific research in all above mentioned aspects.

\section{References}

Aidukaitè, J., Bogdanova, N., Guogis, A. (2012). Gerovès valstybès kūrimasis Lietuvoje: mitas ar realybè? Vilnius: Lietuvos socialinių tyrimų centras. http://1stc.lt/download/Geroves_valstybes_kurimas_visas.pdf

Bannink, D., Hoogenboom, M. J. M. (2007). Hidden change: disaggregation of welfare state regimes for greater insight into welfare state change. Journal of European Social Policy, Vol. 17(1), p. 19-32. https://journals.sagepub.com/ doi/10.1177/0958928707071877

Cousins, M. (2005). European welfare states: comparative perspectives. London: SAGE. DOI: http://dx.doi. org/10.4135/9781446211649.

Esping-Andersen, G. (1990). The three worlds of welfare capitalism. Cambridge: Polity Press. https://press.princeton. edu/titles/4558.html

Fenger, H. S. M. (2007). Welfare regimes in Central and Eastern Europe: incorporating post-communist countries in a welfare typology. Contemporary Issues and Ideas in Social Sciences, Vol. 3 (2), p. 1-30. https://repub.eur.nl/pub/34876/

Ferrera, M. (1996). The „Southern Model“ of Welfare in Social Europe. Journal of European Social Policy, Vol. 6(1), p. 17-37. https://journals.sagepub.com/doi/10.1177/095892879600600102

Genschel, Ph. (2004). Globalization and the welfare state: a retrospective. Journal of European Public Policy, Vol. 11 (4), p. 613-636. https://www.tandfonline.com/doi/abs/10.1080/1350176042000248052

Gingrich, J., Häusermann, S. (2015). The decline of the working-class vote, the reconfiguration of the welfare support coalition and consequences for the welfare state. Journal of European Social Policy, Vol. 25(1), p. 50-75. https:// journals.sagepub.com/doi/abs/10.1177/0958928714556970

Gizelis, T. I. (2005). Globalization, Integration, and the EuropeanWelfare State. International Interactions, Vol. 31 (2), p. 139-162. https://core.ac.uk/download/pdf/318619.pdf

Green-Pedersen, Ch., Jensen, C. (2019). Electoral competition and the welfare state. West European Politics, Vol. 42 (4), p. 803-823. https://www.tandfonline.com/doi/abs/10.1080/01402382.2019.1565736

Guogis, A. (2013). What kinds of new branding in administration is necessary to apply in European public and nonprofit sectors? A particular reference to Eastern European countries. Responsibility and Sustainability, Vol. 1 (2), p. 1-6. http://www.grupomio.org/?attachment_id=412

Harisalo, R., McInerney, J. (2008). Welfare State: From Dream to Reality. International Journal of Public Administration, Vol. 31, p. 10-11; 1303-1326. https://www.tandfonline.com/doi/abs/10.1080/01900690801973501

Hood, Ch. (1991). A public management for all seasons? Public Administration, Vol. 69, Issue 1, p. 3-19. http://newdoc.nccu.edu.tw/teasyllabus/110041265941/Hood\%20NPM\%201991.pdf

Kaarlainen, J., Lehtonen, H. (2006). The variety of social capital in welfare state regimes - a comparative study of 21 countries. European Societies, Vol. 8(1), p. 27-57. https://www.tandfonline.com/doi/abs/10.1080/14616690500491399

Keskinen, S. (2016). From welfare nationalism to welfare chauvinism: Economic rhetoric, the welfare state and changing asylum policies in Finland. Critical Social Policy, Vol. 36(3), p. 352-370. https://journals.sagepub.com/doi/ abs $/ 10.1177 / 0261018315624170$

Lauzadyte-Tutliene, A., Balezentis, T., Goculenko, E. (2018). Welfare state in Central and Eastern Europe. Economics and Sociology, Vol. 11 (1), p. 100-123. http://yadda.icm.edu.pl/yadda/element/bwmeta1.element.ekon-element-000171508018

Lynch, J., Myrskylä, M. (2009). Always the Third Rail? Pension Income and Policy Preferences in European Democracies. Comparative Political Studies, Vol. 42, No. 8, p. 1068-1097. https:/journals.sagepub.com/doi/ abs/10.1177/0010414009331722

Mykolaitytè, K. (2019.02.27). Europos Komisija negailestinga: Lietuvoje kritinė padètis dèl nelygybės. www.delfi.lt; https:// www.delfi.lt/verslas/verslas/europos-komisija-negailestinga-lietuvoje-kritine-padetis-del-nelygybes.d?id=80478205 
Moreno, L. (2016). Post-crisis and the bronze age of welfare in Europe. In S. S. Sanchez-Caberudo, A. L. Pelaez (eds.). The ailing welfare state. Madrid: Thomson Reuters Aranzadi, p. 56-57 (60). http://digital.csic.es/bitstream/10261/177818/1/Post-crisisBronzeAgeWelfare\%20(LuisMoreno)(2016).pdf

Osborne, D., Gaebler, T. (1992). Reinventing government. New York: Addison-Wesley Publ. Co. https://www.tandfonline.com/doi/abs/10.1080/00222216.1995.11949751

Pollitt, Ch., Bouckaert, G. (2011). Public management reform: a comparative analysis - new public management, governance and the Neo-Weberian state. Oxford University Press. https://journals.sagepub.com/doi/ abs/10.1177/0020852312437323

Pop-Radu, I. (2014). The European welfare model. Is Romania a welfare state? Economic Sciences, Vol. 7(56), No. 1, p. 171-178. http://webbut.unitbv.ro/BU2014/Series\%20V/BULETIN\%20V\%20PDF/23_POP-RADU\%20IOANA.pdf

Rakšnys, A. V., Guogis, A., Minkevičius, A. (2015). The problem of reconciliation of new public governance and postmodernism: the conditions of returning to communitarianism. Trames, Vol. 19 (69/64), p. 333-353. http://www.kirj. ee/public/trames_pdf/2015/issue_4/Trames-2015-4-333-353.pdf

Shinyoung, K. (2005). Economic crisis, domestic politics and welfare state changes. The Pacific Review, Vol. 18 (3), p. 375-391. https://www.tandfonline.com/doi/pdf/10.1080/09512740500189090?needAccess=true

Skuodis, M. (2009). Naujųjų Europos Sajungos valstybių gerovės režimų vieta tradicinių Europos socialinių modelių tipologijoje. Filosofija. Sociologija, Nr. 20 (2), p. 130-143. http://mokslozurnalai.lmaleidykla.lt/publ/02357186/2009/2/130-143.pdf

Stambolieva, M. (2015). Welfare State Change and Social Citizenship in the Post-Yugoslav States. European Politics and Society, Vol. 16 (3), p. 379-394. https://www.tandfonline.com/doi/full/10.1080/23745118.2015.1061775?nee dAccess $=$ true

Tache, I., Neesham, C. (2011). The performance of Welfare systems in post-communist Europe: The cases of Romania and Bulgaria. International Journal of Economics and Research, Vol. 2(5), p. 90-107. https://www.semanticscholar. org/paper/THE-PERFORMANCE-OF-WELFARE-SYSTEMS-IN-EUROPE-\%3A-THE-Tache-Neesham/0d39cc0 158cc35feb2fa8b934c1bc401649eacbe

Titmuss, R. M. (1958). Essays on "The welfare state”. London: George Allen: Unwin LTD. https://www.abebooks. co.uk/book-search/title/essays-on-\%27the-welfare-state\%27/author/titmuss-richard-m/

Titmuss, R. M. (1974). What is social policy? In S. Leibfried, S. Mau (eds.) (2008). Welfare states: construction, deconstruction, reconstruction, Vol. 1. http://www.sfb597.uni-bremen.de/download/en/publikationen/sfbReihen_toc_ Welfare_States.pdf

\title{
GEROVÉS VALSTYBÉS MODELIŲ, JU巳 VERTYBIU IR SUDERINAMUMO SU VIEŠOJO ADMINISTRAVIMO MODELIAIS PROBLEMA
}

\author{
Arvydas Guogis, Adomas Vincas Rakšnys
}

Mykolo Romerio universitetas (Lietuva), Kazimiero Simonavičiaus universitetas (Lietuva)

\section{Santrauka}

Gerovès valstybių modelių kūrimo problema egzistuoja jau ne vieną dešimtį metų. Ypatingas vaidmuo, siekiant socialinès kokybės, kai kuriamos gerovès valstybės, tenka vertybių puoselejjimo klausimui. Autoriai straipsnyje šiuo aspektu kelia originalią gerovès valstybès ir viešojo administravimo modeliu atitikimo bei jų suderinamumo problemą tiek Vakaruose, tiek ir Centrinès bei Rytų Europos šalyse. Jų teigimu, liberalus marginalinis gerovès valstybès modelis anglosaksiškose šalyse generuoja naujają viešają vadybą ir atvirkščiai, o korporatyvus-konservatyvus gerovės valstybės modelis labiau atitinka hierarchini viešojo administravimo modelị kontinentinès Vakarų Europos valstybėse. Tam tikri naujojo viešojo valdymo bruožai atskleidžia labiau universalų perskirstomaji socialdemokratinị modelį kūrusiose Šiaurès Europos šalyse. Kyla klausimas dèl Pietų, Centrinès ir Rytų Europos gerovės valstybės modelių, kuriems, be „bismarkinių“ 
korporatyvaus modelio savybių, būdingi ir klientelistiniai atitikimo hierarchiniam viešojo administravimo modeliui elementai, nes pastaruoju metu jie „dreifavo“ liberalaus marginalinio modelio link. Dèl klientelistinių bruožų (nepotizmo, korupcijos, protekcionizmo, mažo nevyriausybinių ir politinių organizacijų aktyvumo) šioms valstybėms aktualus naujojo viešojo valdymo elementų formulavimas ir jų igyvendinimas. Bet kuriuo atveju gerovès valstybės modelių ir jų atitikimo bei suderinamumo problema yra aktuali teorinè ir praktinè problema tiek Vakaruose, tiek Centrinės bei Rytų Europos šalyse.

PAGRINDINIAI ŽODŽIAI: gerovès valstybès modeliai, viešojo administravimo modeliai, vertybès, atitikimas, suderinamumas, Naujasis viešasis valdymas.

JEL KLASIFIKACIJA:

Received: 2019-09

Revised:2019-09

Accepted:2019- 